\title{
UMMB TEMULAWAK (Curcuma xanthorrhiza) SEBAGAI SUPLEMEN PAKAN TERNAK RUMINANSIA
}

\author{
UMMB Temulawak (Curcuma xanthorrhiza) as a Ruminant Feed Supplement \\ Siti Chuzaemi*1), Muhammad Halim Natsir ${ }^{1)}$, Osfar Sjofjan ${ }^{1)}$, Addharul Muttaqin ${ }^{2}$, \\ Yuli Frita Nuningtyas ${ }^{1}$, dan Asri Nurul Huda ${ }^{1)}$ \\ ${ }^{1)}$ Dosen Minat Nutrisi dan Makanan Ternak, Fakultas Peternakan, Universitas Brawijaya, Malang, Jawa Timur, \\ Indonesia, 65145 \\ ${ }^{2)}$ Dosen Fakultas Teknik, Universitas Brawijaya, Malang, Jawa Timur, Indonesia, 65145 \\ E-mail: schuzaemi@ub.ac.id \\ Diterima Pasca Revisi: 27 Februari 2020 \\ Layak Diterbitkan: 1 Maret 2020
}

\begin{abstract}
ABSTRAK
Tujuan dari kegiatan ini adalah untuk menganalisis bagaimana respon ternak sapi perah terhadap produk Urea Molasses Medicated Block (UMMB) Temulawak. Adapun percobaan dilakukan di Laboratorium Lapang Sumber Sekar, Faculty of Animal Science, University of Brawijaya yang terseltan di Desa Sumber Sekar, Kecamatan Dau, Kabupaten Malang. Kegiatan ini terdiri dari : 1) Pembuatan formulasi UMMB Temulawak; 2) produksi UMMB Temulawak; 3) pemberian pakan pada lima ekor sapi perah laktasi; 4) evaluasi ;5) sosialisasi pada peternak sapi perah di sekitar lokasi Laboratorium Lapang Sumber Sekar. Metode dari kegiatan ini adalah percobaan pemberian pakan pada ternak, konseling dan produksi. Percobaan pemberian UMMB Temulawak pada ternak menunjukkan respon yang baik. Sapi perah tertarik pada produk UMMB karena aroma molassesnya yang mampu meningkatkan palatabilitas ternak. Kegiatan penyuluhan kepada masyarakat peternak di Desa Sumber Sekar pun menuai reaksi positif. Kekhawatiran mereka terhadap urea sudah terbantahkan dengan kondisi ternak yang tetap baik seusai mengonsumsi UMMB. Peternak juga mendapatkan informasi baru mengenai Temulawak dalam produk UMMB sebagai suplemen anti parasit. Kesimpulan dari kegiatan ini adalah produksi UMMB Temulawak dalam skala besar dapat dikerjakan karena memiliki potensi pasar yang besar terlihat dari antusiasme peternak sapi perah di Desa Sumber Sekar.
\end{abstract}

Kata Kunci: Temulawak, urea, molasses, medikasi

How to Cite:

Chuzaemi, S., Natsir, M. H., Sjofjan, O., Muttaqin, A., Nuningtyas, Y. F., \& Huda, A. N. (2020). UMMB Temulawak (Curcuma Xanthorrhiza) Sebagai Suplemen Pakan Ternak Ruminansia. Jurnal Nutrisi Ternak Tropis, 3(1) 23-29
*Corresponding author:

Siti Chuzaemi

Email: schuzaemi@ub.ac.id

Dosen Minat Nutrisi dan Makanan Ternak, Fakultas

Peternakan, Universitas Brawijaya, Malang, Jawa

Timur, Indonesia, 65145 


\section{ABSTRACT}

The objectives of this feeding trial was to identify the Urea Molasses Medicated Block (UMMB) Temulawak product on lactating dairy cows in Field Laboratory, Faculty of Animal Science, University of Brawijaya, where located in Sumber Sekar Village, Dau Sub-districts, Malang District. The activities consist of: 1) UMMB Temulawak formulation, 2) produce good quality UMMB Temulawak (small scale), 3) Feeding trial to 5 lactating dairy cows 4) Evaluation, and 5) Socialization to small-scale dairy farmers in Sumber Sekar Village, Dau Sub-districts, Malang District. The method in this activity was feeding trial in the farm, counselling, and producing. UMMB Temulawak feeding trial showed good effect to cow palatability and feed intake because of the molasses. Temulawak also gave good flavour to the cows. The community service activity to farmers also had a positive impact. They got new information about feed supplement "UMMB Temulawak" which also function as a medicated especially anthelmintic effect to ruminant animals. They also improve their skill to formulate UMMB Temulawak as a feed supplement for the dairy cows. The conclussion of this activity was the production of large scale UMMB Temulawak can be conducted further because it has good market potential, seen from enthusiasm of the community of dairy cows farmers at the Sumber Sekar Village.

Keywords: Curcuma xanthorrhiza, urea, molasses, medicated

\section{PENDAHULUAN}

Sebagian besar usaha peternakan sapi perah di Indonesia merupakan usaha peternakan rakyat dengan skala kecil atau menengah. Usaha peternakan sapi perah rakyat penghasil susu semakin meningkat untuk memenuhi kebutuhan protein hewani. Namun permasalahan yang dihadapi oleh peternak sapi perah atau ternak ruminansia yaitu rendahnya kualitas pakan terutama pada musim kemarau.

Kondisi terseebut membuat peternak memberikan pakan berupa limbah pertanian yang kandungan nutrisinya rendah misalnya jerami padi. Jerami padi adalah salah satu limbah pertanian yang memiliki keterbatasan dikarenakan karakteristik dinding selnya yang sulit dicerna oleh mikroorganisme rumen (Yanuartono, dkk. 2016). Selain itu di Indonesia penyakit yang biasa menyerang ternak ruminasia berupa parasit khususnya adalah cacing, Cacing parasit mampu menyerap zat makanan dan menghisap darah ataupun cairan tubuh (Lili, 2017). Salah satu cara yang digunakan untuk meningkatkan kualitas pakan dan juga sebagai pengobatan untuk sapi perah yaitu dengan pemberian UMMB (Urea Molases
Medicated Block). UMMB merupakan salah satu imbuhan pakan yang diberikan untuk ternak ruminansia seperti sapi perah, sapi potong dan kambing untuk meningkatkan kecernaan dan juga mengobati penyakit terutama penyakit cacingan. UMMB terdiri dari bahan-bahan seperti urea, molases, bahan pengisi, dan tanaman herbal seperti temulawak. Manfaat urea untuk ternak ruminasia yaitu sebagai bahan sumber NPN (Non Protein Nitrogen) (Bach et all. 2015 dalam Yanuar dkk 2017). Molases digunakan sebagai bahan sumber energi terlarut untuk mikroba rumen. Bahan pengisi yang digunakan untuk UMMB diantaranya adalah polar, dedak,dan bungkil kedelai. Sedangkan medicated yang digunakan berupa tanaman herbal seperti temulawak dan temuireng. Temulawak berfungsi sebagai anthelmintic yaitu menurunkan jumlah telur cacing pada tubuh ternak ruminansia (Saleh et all,2016).

Laboratorium Lapang Sumber Sekar Fakultas Peternakan UB memiliki beberapa ekor sapi perah yang digunakan sebagai media untuk penelitian maupun praktikum mahasiswa Fakultas Peternakan, dimana pemeliharaan sapi perah di laboratorium tersebut masih kekurangan nutrisi terutama 
sumber $\mathrm{N}$ dan energi sehingga produktifitas rendah. Kegiatan ini bertujuan untuk 1) membuat forrmulasi UMMB temulawak, 2) produksi UMMB temulawak skala kecil 3) uji coba menggunakan 5 ekor ternak sapi perah di Lab. Sumber Sekar, 4) evaluasi uji coba produk UMMB temulawak 5) dilakukan sosialissai kepada masyarakat peternak sapi di Desa Sumber Sekar

\section{MATERI DAN METODE}

Kegiatan produksi Urea Molasses Medicated Block (UMMB) Temulawak perlu dilakukan secara berkelanjutan. Dalam rangka pengujian produk UMMB Temulawak, tahap-tahap yang dilakukan adalah uji coba formula UMMB Temulawak dengan produksi skala kecil, uji coba pemeberian kepada ternak, analisis fisik dan kimia, sosialisasi kepada masyarakat peternak dan evaluasi produk.

Produksi UMMB Temulawak dalam skal besar dapat dilakukan apabila evaluasi menunjukkan hasil yang baik. Kegiatan ini dilakukan mulai Bulan Agustus 2019 berlokasi di Gedung 3 Fakultas Peternakan Universitas Brawijaya. Uji coba pemberian UMMB Temulawak pada ternak sapi perah dilakukan di Laboratorium Sumber Sekar, Fakultas Peternakan Universitas Brawijaya. Adapun uji coba pada ternak secara langsung perlu dilakukan untuk melihat tingkat palatabilitas ternak terhadap produk UMMB Temulawak dan efeknya terhadap ternak.

Uji coba ini diharapkan dapat membuktikan kepada masyarakat peternak bahwa urea merupakan sumber $\mathrm{N}$ yang dapat dikonsumsi oleh ternak tanpa bersifat racun. Jumlah sapi perah laktasi yang digunakan untuk uji coba UMMB Temulawak adalah 5 ekor. Metode yang digunakan dalam kegiatan ini adalah:

1. Membuat formulasi UMMB Temulawak

a) Formulasi dibuat berdasarkan literatur / penelitian sebelumnya b) Proporsi UMMB Temulawak dibuat $10 \%$ dari keseluruhan bahan penyusun

c) Bahan pengisi merupakan bahanbahan yang tersedia di lokasi uji coba / bahan lokal

2. Produksi UMMB Temulawak skala kecil a) Produksi UMMB Temulawak dilakukan dengan total berat per $30 \mathrm{~kg}$

b) Pencetakkan UMMB Temulawak dilakukan dengan mesin cetak (seperti alat cetak paving)

3. Uji coba kepada 5 ekor sapi perah laktasi di Lab. Lapang Sumber Sekar FPt UB

a) Uji coba dilakukan dengan meletakkan UMMB Temulawak di atas palungan pakan

b) Setiap satu blok UMMB Temulawak dikonsumsi oleh dua ekor sapi perah laktasi yang letaknya bersebelahan

c) Pengamatan dilakukan terhadap palatabilitas ternak, berapa lama ternak menghabiskan UMMB Temulawak dan bagaimana kondisi ternak (konsumsi bertambah atau bafsu makan mengalami penurunan)

4. Evaluasi kegiatan uji coba produk UMMB Temulawak

a) Evaluasi dilakukan berdasarkan hasil uji coba UMMB Temulawak pada 5 ekor sapi perah di Lab. Lapang Sumber Sekar.

5. Sosialisasi kepada masyarakat peternak sapi perah di sekitar lokasi yaitu Desa Sumber Sekar, Kec. Dau, Kabupaten Malang

a) Sosialisasi dilakukan kepada masyarakat peternak sapi perah di sekitar Laboratorium Lapang Sumber Sekar, FPt UB

b) Masing-masing peternak mendapatkan satu buah UMMB Temulawak untuk dicobakan kepada ternaknya

c) Praktik pembuatan UMMB Temulawak bersama peternak 


\section{HASIL DAN PEMBAHASAN}

\section{Lokasi Kegiatan}

Kegiatan uji coba UMMB Temulawak dilakukan pada ternak sapi perah laktasi yang ada di Lab. Lapang Sumber Sekar, Fakultas Peternakan Universitas Brawijaya, Malang.

Keberadaan Laboratorium Lapang tersebut sedikit banyak memberikan pengaruh pada masyarakat peternak di sekitarnya. Masyarakat banyak belajar manajemen pemeliharaan dan pemberian pakan serta reproduksi ternak dari Lab. Lapang Sumber Sekar, maka setelah dilakukan uji coba produk kemudian dilanjutkan dengan sosialisasi produk UMMB Temulawak pada masyarakat peternak di sekitar lokasi. Desa Sumber Sekar merupakan salah satu desa yang terletak di Kecamatan Dau, Kabupaten Malang.

Desa Sumber Sekar memiliki potensi peternakan yang baik, khususnya ternak ruminansia seperti sapi perah, kambing dan domba. Rata-rata kepemilikikan sapi perah adalah 2-3 ekor sapi laktasi per kepala keluarga. Produksi susu rata-rata pada tahun 2019 adalah 8-9 liter / ekor/ hari. Antusiasme masyarakat terhadap produk UMMB Temulawak menggambarkan bahwa Desa Sumber Sekar memiliki potensi pengembangan peternakan ruminansia.

\section{Formulasi UMMB Temulawak}

Tabel 1 menyajikan komposisi proporsi bahan-bahan penyusun UMMB Temulawak yang diproduksi dalam kegiatan ini. Urea berperan sebagai bahan sumber NPN (Non Protein Nitrogen) bagi ternak ruminansia. NPN dalam tubuh ternak ruminansia dibutuhkan sebagai nutrient bagi mikroba rumen dan $80 \%$ sel mikroba $\mathrm{N}$ berasal dari ammonia. Protozoa rumen tidak dapat menggunakan $80 \%$ sel mikroba $\mathrm{N}$ tersebut (Bach et all., 2015 dalam Yanuar dkk., 2017). OH pada Urea mampu memutus ikatan Hidrogen antara Oksigen pada Carbon nomor 2 dan Oksigen nomor 6 pada molekul glukosa, sehingga dapat memecah selulosa, hemiselulosa dan lignoselulosa dinding sel tanaman pakan ternak (Yanuarto dkk., 2017).

Molasses merupakan bahan sumber energy terlarut untuk mikroba rumen. Bahan-bahan lain seperti pollar, dedak, bungki kedelai adalah bahan pengisi dalam pembuatan UMB. Bahan-bahan pengisi tersebut terdiri dari bahan pakan sumber protein yaitu bungkil kedelai dan bungkil kelapa, pollard dan dedak sebagai sumber energy. Bahan-bahan lain seperti vitamin dan mineral juga ditambahkan untuk memperkaya kandungan nutrient dalam UMMB.

Proses pembuatan UMMB juga memerlukan Calcium silicate atau semen yang berfungsi sebagai behan pengeras. UMMB secara fisik harus dalam keadaan keras agar ternak tidak berlebihan dalam mengkonsumsi UMMB.Konsumsi yang berlebihan terhadap UMMB dikhawatirkan bisa meracuni ternak. Temulawak (Curcuma xanthorrhiza) mengandung senyawa seperti anti diuretic, anti- inflamasi, antihepatotoxic, anthelmintic, antibacterial dan antifungal (Salleh et all., 2016). Penggunaan temulawak dikombinasikan dengan temu ireng di dalam UMMB mampu menurunkan jumlah telur cacing dalam tubuh ternak ruminansia. Telur cacing banyak terdapat ada hijauan pakan ternak dimana cacing tersebut nantinya dapat berkembang biak di saluran pencernaan ternak dan menyebkan infeksi sehingga bisa menghambat pertumbuhan ternak dan pada kondisi yang ekstrim bisa menyebabkan kematian ternak.

Temulawak juga dapat mencegah mastitis pada sapi perah dengan mencampur mencampur temulawak dalam pakan (Harjanti et all., 2009). Sebesar 15\% larutan temulawak dalam 450 gram tabut blok (tape singkong dan urea blok) berpengaruh terhadap produksi susu sapi perah $\mathrm{PFH}$. Kandungan nutrisi dari temulawak disajikan dalam Tabel 2. 
Tabel 1. Formulasi Bahan Penyusun UMMB Temulawak

\begin{tabular}{lcl}
\hline \multicolumn{1}{c}{ Bahan Baku } & Proporsi $(\%)$ & \multicolumn{1}{c}{ Sumber } \\
\hline Urea & 4 & $\mathrm{~N}$ \\
Molasses & 60 & Energi dan Perekat \\
Pollard & 13 & Energi dan Absorbent \\
Bungkil Kelapa & 10 & Protein \\
Mineral Mix & 4 & Mineral \\
Semen & 2 & Pengeras \\
Garam & 1 & Mineral/palatabilitas \\
Curcuma xanthorrhiza (Temulawak) & 6 & Meditaced (M-UMB) \\
\hline Jumlah & 100 & \\
\hline
\end{tabular}

Tabel 2. Kandungan Nutrisi Temulawak

\begin{tabular}{cccccc}
\hline & BK $(100 \%)$ & BO $^{*}(\%)$ & PK* $^{*}(\%)$ & SK $^{*}(\%)$ & LK* $\left.^{*} \%\right)$ \\
\hline Temulawak & 93,25 & 10,17 & 12,42 & 8,65 & 6,72 \\
\hline
\end{tabular}

Sumber: Hasil analisis proksimat di Laboratorium Nutrisi dan Makanan Ternak, FPt UB *Berdasarkan 100\% Bahan Kering

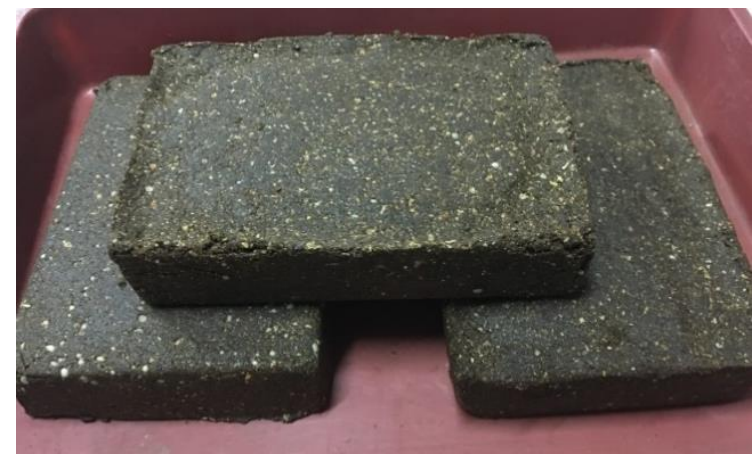

Gambar 1. Produk UMMB

Produk UMMB pada Gambar 1 tersebut telah diproduksi oleh anggota PPUPIK kemudian diujicobakan kepada ternak sapi perah laktasi di Lab. Lapang Sumber Sekar, FPt UB. Kandungan PK dari bahan penyusun UMMB Temulawak dalam penelitian ini adalah $17,116 \%$ dan $82,213 \%$ BK. Molasses yang ada dalam UMB tersebut mampu menstimulate palatabilitas ternak terhadap UMMB.

Setelah mengkonsumsi UMMB, ternak memiliki nafsu makan yang lebih baik untuk mengkonsumsi pakan basalahnya yaitu rumput dan konsentrat. UMMB pada Gambar 1 tersebut memiliki berat rata-rata satu buah sebesar $800-1.000$ g. Konsumsi UMMB oleh ternak ruminansia besar bervariasi antara 150-300 gram/ ekor/ hari sedangkan pada kambing dan domba 12 gram/ekor/hari (Faizi et all, 2004). Jadi, UMMB tersebut bisa habis dalam 2-3 hari per ekor sapi perah. Teknis pemberian UMMB bisa digantung di atas palungan pakan atau diletakkan di pinggir palungan pakan. Ternak kambing biasanya akan mengonsumsi UMMB secara berkelompok karena bentuk kandang yang umbaran sedangkan untuk sapi perah satu UMMB untuk dua ekor.

Pakan basal yang diberikan kepada sapi perah laktasi di Lab. Lapang Sumber Sekar adalah rumput gajah dan pakan tambahan berupa konsentrat. Rataan konsumsi BK pakan 5 ekor sapi perah sebelum ditambah suplemen UMMB adalah $2,89 \% \pm 0,19$ dari bobot badan ternak sedangkan pasca pemberian UMMB selama 30 hari meningkat menjadi 3,02\% $\%$ 0,29 dari bobot badan ternak. Sapi perah memiliki ketertarikan untuk mengonsumsi UMMB Temulawak karena aromanya yang manis berasal dari molasses sangat kuat. 
Peningkatan palatabilitas tersebut diikuti dengan peningkatan konsumsi Bahan Kering (BK) pakan seperti penelitian yang dilakukan leh Mirza et all (2002) dengan pemberian UMB mampu meningkatankan konsumsi pakan, pertambahan bobot badan dan kualitas karkas Sapi Zebu.

UMMB mampu meningkatkan pertumbuhan dan aktifitas mikroba rumen sehingga membuat ternak mampu mengkonsumsi hijauan / pakan sumber serat lebih banyak (De and Singh, 2002). UMMB yang diberikan pada ruminansia kecil seperti kambing perah laktasi pun menunjukkan efek positif yaitu meningkatnya konsumsi pakan, walaupun tidak signifikan meningkatkan bobot badan ternak (Mira et all., 2018).

\section{KESIMPULAN}

Pemberian UMMB pada ternak sapi perah laktasi memberikan dampak positif yaitu meningkatnya nafsu makan ternak dikarenakan aroma molasses dalam UMMB. Tambahan Temulawak sebagai salah satu tanaman herbal Indonesia digunakan sebagai campuran dalam pembuatan UMMB memiliki senyawa anti parasite untuk ternak. UMMB adalah metode yang paling aman dalam memberikan urea sebagai sumber $\mathrm{N}$ pada ternak. Penelitian perlu dilakukan untuk menganalisis bagaimana efek medicated UMMB Temulawak pada sapi perah atau pada ternak ruminansia lain. Informasi ini akan sangat dibutuhkan oleh masyarakat peternak dan menambah nilai produk UMMB Temulawak.

\section{DAFTAR PUSTAKA}

De, D., \& Singh, G. P. (2002). Monensin enriched urea molasses mineral block on feed intake, nutrient digestibility and blood glucose in cattle fed on wheat straw based diet. AsianAustralasian Journal of Animal Sciences, 15(11), 1579-1584. https:// doi.org/10.5713/ajas.2002.1579
Faizi, M. U., Siddiqui, M. M., \& Habib, G. (2004). Effect of urea molasses block supplementation on nutrien digestibility and intake of ammoniated maize stovers cow-calves. Pakistan Journal, 24(1), 13-17.

Harjanti, D. W., Wahyono, F., \& Afifah, D. N. (2009). Milk Production and Milk Quality of Subclinical Mastitis Cow Feed with Different Supplementation of Herbal in The Diet. IOP Conference Series: Earth and Environmental Science.

Mira, P., Wan Zahari, M., Rusli, N. D., \& Mat, K. (2018). Effects of nonmedicated and medicated urea molasses multi-nutrient blocks on dry matter intake, growth performance, body condition score and feed conversion ratio of saanen lactating does fed conventional diets. Tropical Agricultural Science, 24(2), 729-740.

Mirza, I. H., Khan, A. G., Azim, A., \& Mirza, M. A. (2002). Effect of supplementing grazing cattle calves with urea-molasses blocks, with and without yucca schidigera extract, on performance and carcass traits. AsianAustralasian Journal of Animal Sciences, 15(9), 1300-1306. https:// doi.org/10.5713/ajas.2002.1300

Salleh, N. M., Ismail, S., \& Ab Halim, M. (2016). Effects of Curcuma xanthorrhiza extracts and their constituents on phase ii drug-metabolizing enzymes activity. Pharmacognosy Research, 8(4), 309315. https://doi.org/10.4103/0974-8490 .188873

Sulistyowati, E. (2009). Kinerja temulawak (C. xanthorrhiza Roxb.) dalam tabut blok dan konsentrat terhadap produksi susu dan lemak susu ruminansia laktasi. Jurnal Tumbuhan Obat Indonesia, 2(2), 79-86. 
Yanuartono, Nururrozi, A., Indarjulianto, S., Purnamaningsih, H., \& Rahardjo, S. (2018). Urea : manfaat pada ruminansia. Jurnal Ilmu-Ilmu Peternakan, 28(1), 10-34. https://doi.org/10.21776/ub.jiip. 2018.028.01.02

Yanuartono, Y., Indarjulianto, S., Nururrozi, A., Purnamaningsih, H., \& Raharjo, S. (2019). Urea molasses multinutrien blok sebagai pakan tambahan pada ternak ruminansia. Jurnal Veteriner, 20(3), 445-451. https://doi.org/10.19 087/jveteriner.2019.20.3.445
Zalizar, L. (2017). Helminthiasis saluran cerna pada sapi perah. Jurnal IlmuIlmu Peternakan, 27(2), 1-7. https://doi. org/10.21776/ub.jiip.2017.027.02.01 